\title{
Dijitalleşme ve Dijital Sosyal Sorumluluk Iletişimi
}

Başvuru Tarihi: 20.11.2020 Yayın Kabul Tarihi: 24.12 .2020 Yayınlanma Tarihi: 30.12 .2020

\author{
Zeynep Mine Alptekin ${ }^{1}$ \\ istanbul Ticaret Üniversitesi \\ minealptekin@hotmail.com \\ (iD) ORCID: 0000-0002-7580-6920
}

\section{ÖZET}

Bu çalışmanın amacı dijitalleşme kavramını incelemek, kurumsal sosyal sorumluluk kavramının dijitalleşme dikkate alarak nasıl farklılaştığını örnekleri ile tanımlamaktır. Şirketlerin yaptığı çalışmaların kurumsal sosyal sorumluluk girişimlerinin farklı alanlardaki iletişimi ve gelişimi ile nasıl kanıtlandığı değerlendirilmiştir. Yeni teknolojinin getirdiği fırsatları şirketlerin nasıl ve hangi amaçla kullandığı, kurumsal sosyal sorumluluktan dijital sosyal sorumluluk geçişinde dijital dönüşüm kavramı nasıl etkinliğini gösterdiği ve hangi veriler sonrasında oluştuğu sorgulanmıştır. Araştırmada yabancı kaynaklar desteği ile dijital sosyal sorumluluk ve bu konuda yapılan çalışmalara yönelik bilgiler değerlendirilmiştir. Her ne kadar dijitalleşmenin, sosyal sorumluluk projelerindeki katkısı ve etkisi farklı örnekler ile gösterilmiş olsa da halen bu kanalları etkin kullanmayan şirketlerin olması da değerlendirilmektedir. Çalışmada paydaş teorisi üzerinden tek ve iki yönlü iletişim yaklaşımları incelenmiş ve çift yönlü iletişimde dijitalleşmenin etkisi belirtilmiştir. Çevrim içi ağları mesajlarını iletmek ve faaliyetlerini duyurmak amacıyla kullanan şirketlerin, kurumsal sosyal sorumluluk faaliyetlerine olan katkılarını ölçümleyen örnekler üzerinden betimsel bir analiz yapılarak değerlendirilmiştir. Araştırmanın sonucunda, yeni bir kavram olan dijital sosyal sorumluluk ile iletişimin etkin ve yerinde kullanımının faydaları ve dijitalleşme sürecindeki en etkin iletişim kanalları olduğu belirtilmiştir.

Anahtar Kelimeler: Kurumsal Sosyal Sorumluluk, Paydaş, Dijital Sorumluluk, İki Yönlü İletişim, Sosyal Ağ.

${ }^{1}$ Doktora Öğrencisi. İstanbul Ticaret Üniversitesi. 


\title{
Digitalization and Digital Social Responsibility Communication
}

Zeynep Mine Alptekin ${ }^{2}$

istanbul Commerce University

minealptekin@hotmail.com

(iD) ORCID: 0000-0002-7850-6920

\begin{abstract}
The purpose of this study is to examine the concept of digitalization and to describe how the concept of corporate social responsibility differs by considering digitalization with examples. It was evaluated how the work carried out by the companies was proven by the communication and development of corporate social responsibility initiatives in different fields. It has been questioned how and for what purpose companies use the opportunities brought by new technology, how the concept of digital transformation shows its effectiveness in the transition from corporate social responsibility to digital social responsibility, and after which data it occurs. In the research, information about digital social responsibility and studies on this subject with the support of foreign resources were evaluated. Although the contribution and effect of digitalization in social responsibility projects have been shown with different examples, it is also considered that there are companies that do not use these channels effectively. In the study, one-way and two-way communication approaches were examined through stakeholder theory and the effect of digitalization in two-way communication was stated. A descriptive analysis is made and evaluated through examples that measure the contributions of companies that use online networks to convey their messages and announce their activities to corporate social responsibility activities. As a result of the research, it was stated that digital social responsibility, which is a new concept, and the benefits of effective and appropriate use of communication, are the most effective communication channels in the digitalization process.
\end{abstract}

Keywords: Corporate Social Responsibility, Stakeholder, Digital Social Responsibility, Two-way Communication, Social Network.

\footnotetext{
${ }^{2}$ Ph.D. Student. İstanbul Commerce University.
} 


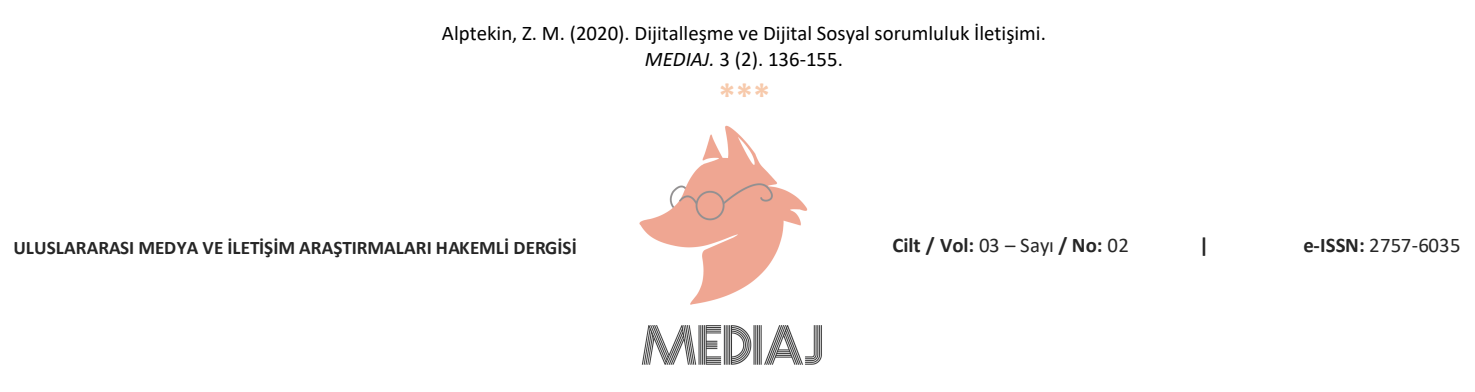

\section{Giriş}

Internet'in ve world wide web'in halkla ilişkiler sürecinin hızını arttırma potansiyeline sahip olmaları (Esrock ve Leichty, 1998, s.308) her geçen gün, kurumların kurumsal sosyal sorumluluk çalışmalarını çevrimiçi ortama taşımalarını zorunlu hale getirmektedir. Tek yönlü iletişimden çift yönlü iletişime geçişi sağlayan ve ilk olarak Tim O'Reilly tarafından kullanılan Web 2.0, bloglar, sosyal ağlar ile ilgili platformların gelişimini sağlamıştır (Fieseler, vd., 2010, s. 601). Web 2.0'nin hayatımıza kazandırdığı sosyal medya gibi yeni iletişim ortamları, daha fazla iletişim dinamiklerine sahip olup, interaktif iletişimi büyük bir hızda ve coğrafi dağılımda daha geniş kitlelere birkaç saat içerisinde tüm çevrelere yaymaktadır (Schultz vd., 2013, s. 681).

Kurumsal sosyal sorumluluk hem araştırmacılar hem de uygulayıcılar tarafından her zaman ilgiyle takip edilen faaliyetlerdir. Şirketlerin odaklandığı faaliyetler ve projeler, kadın haklarını savunmak, çevreyi korumak, yerel, ulusal veya küresel düzeylerde yoksulluğu ortadan kaldırmaya çalışmak gibi konular olabilir. Tüm farklı kapsamdaki sorumluluk faaliyetleri sosyal ağların kullanımı ile toplum tarafından daha etkilerinin daha güçlü olduğu ölçümlenmiştir. Sosyal sorumluluk faaliyetlerinde yer alan şirketler teknoloji yardımıyla hem tüketicilere hem de paydaşlara daha çekici paylaşımlar sunup dikkati ve ilgili geliştirebilirler. Sonuçlar, şirket karlarını olumlu yönde etkilemeye hizmet eder. Sosyal sorumluluk sahibi şirketler, pozitif marka tanınırlığını geliştirmek, müşteri sadakatini artırmak hedefindedir. Bir diğer yandan bu unsurlar, artan karlılık ve uzun vadeli finansal başarı elde etmenin anahtarları arasındadır (Murhphy, 2019). Şirketlerin üretimleri veya ürünleri ne kadar bilinir veya tanınır bile olsa, topluma, çevreye yaptıkları projelerle insanlar üzerinde çok daha etkin ve bağlı bir kitle oluşturma fırsatlarını teknolojinin avantajları ile kullanabilirler.

Kurumsal sosyal sorumluluk, şirket performansını artıran ve toplumu destekleyen bir rekabet avantajı olarak tanımlanabilir. İşte tam bu noktada dijital teknoloji kanalları devreye girdiğinde, yeni iş uygulamalarının şekillendirilmesinde ve tüketici davranışının değiştirilmesinde kritik bir rol oynayabilir. Sosyal ağlar sayesinde, farklı platformların geniş bir iletişim kanalına sahip olması sebebi ile, müşterilerin çevrimiçi iletişim kurarak zamandan tasarruf etmelerine ve istedikleri kaynağa kısa sürede ulaşmalarına yardımcı olur.

Dijital sosyal sorumluluk, dijital dünyanın etik ilkeler temelinde şekillendirilmesine aktif katılım anlamına gelir. Örneğin, şirketler dijital olarak kendi kaderini tayin etmeyi, veri kullanımında açıkça tanımlanmış sınırlar koymayı ve müşterilere veri toplamalarının kapsamı ve amacı hakkında kapsamlı ve şeffaf bilgiler sağlamayı taahhüt edebilir (Eissfeller, 2020). Geleneksel pazarlama ve iletişim yöntemleriyle çevre ve toplum odaklı projelerini yönetmeyi tercih eden şirketler vardır. Fakat artık günümüzde mobil telefonların her türlü sosyal ağa kolaylıkla erişildiği, sosyal medya kanalları ile dünyadaki tüm olayları anında takip ettiğimiz bir dönemde tercih, dijital kanalların kullanılması üzerine gelişmektedir. Yeni nesillerin dijitalleşme ile doğan ve 


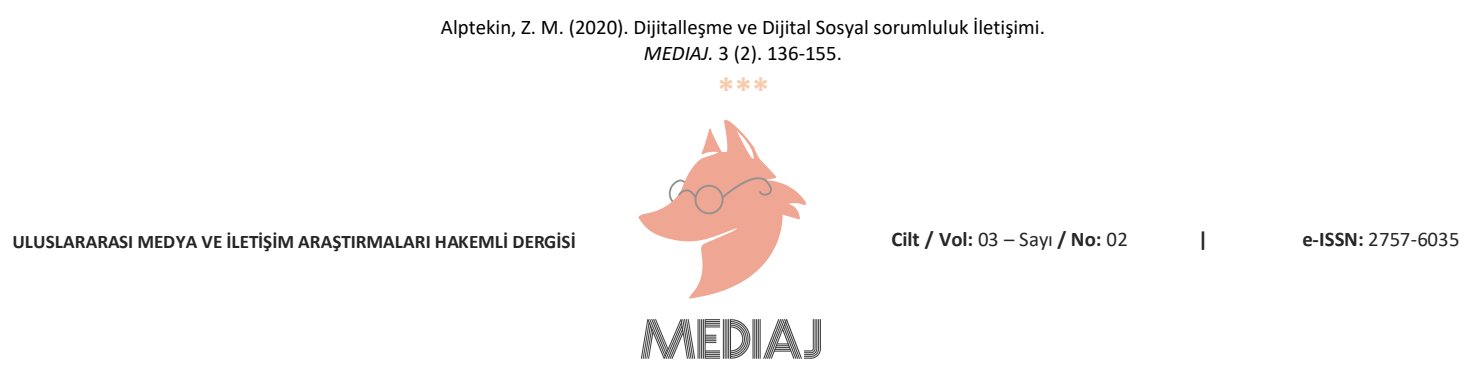

büyüyen bir topluluk olarak ifade edildiği bir çağda, sosyal ağların etkisi dikkate alınmadan bir sorumluluk faaliyetinin sürdürülebilir iletişim sağlaması beklenemez.

Sosyal ağlar, bloglar, video platformları, mikro bloglar ve web siteleri gibi sosyal medya olarak da adlandırılan yeni dijital kanalların sosyal sorumluluk projelerindeki katkısı farklı kampanya ve iletişim yöntemleri ile görülmektedir (Castelló ve Ros, 2012). Sosyal medya terimi, şirketin kendisi, müşteriler, olasılıklar ve etki faktörleri dahil olmak üzere birçok paydaş arasındaki etkileşimlere dayanmaktadır (Vernuccio, 2014; O'Leary, 2011). Genel olarak sosyal medya, Facebook, Linkedin ve Twitter gibi, sosyal etkileşim için platformlar arasında bilgi üretimi, tüketimi ve alışverişi olarak tanımlanabilir (Dutot, 2013, s. 55). Önemli olan hangi sosyal medya kanalının kullanıldığı değildir. Önemli olan en etkili iletişimin hangi sosyal ağlar kullanılarak yapılabileceğidir. Bu fırsatı şirketlerin doğru analizlerle değerlendirmesi gerekir.

Sosyal medyanın ulaştığı tüm kanallar tüketicilerin istediği her bilgiye kolaylıkla ulaşmasını sağlar. Mesela bir müşteri alacağı ürün ile ilgili istediği tüm detayları öğrenebilir. Rakiplerdeki benzeri ürünleri görebilir, ücret karşılaştırması yapabilir ve eleştirileri okur. Ürün ile ilgili üretim yapan şirket hakkında olumlu veya olumsuz çıkan tüm haberlere hızlıca ulaşabilir. Topluma, çevreye karşı sorumlu ve sürdürülebilir çalışmaları olduğuna bakabilir, ne kadar çok sosyal medyada müşteri ile iletişimde olduğuna bakabilir. Aynı şekilde kendi değerlendirmelerini de sosyal medya kanalları ile duyurabilir. Örneğin, müşteriler sosyal medya kanallarından biri olan 'twitter' kullanıp değerlendirmesini bir mesaj olarak kullanıcılara göndermek anlamına gelen 'retweet' eder. Bir başka popüler sosyal medya kanalı 'Instagram' kullanıp, ürün veya hizmetle ilgili deneyimini kısa süreli hikâye paylaşımları bulunulabilen 'story' içinde yazılı veya video ile yer verir. Böylelikle, projelerin daha çok bilinir, tanınır olmasına veya eleştirilmesine fark etmeden katkıda bulunur.

\section{Dijitalleşme ve Dijital Dönüşüm}

Hayatın tüm alanlarının dijitalleşmesi toplumlarımıza hissedilir değişiklikler getirmektedir. Özellikle 2020 yılının başlarından itibaren hayatımızda yer alan salgın hastalık sürecinde dijitalleşmeye öncelik vermeyen veya uzak olan hem bireyler hem de kurumlar, bir çoğumuzun ofis ortamına veya okullara gidemediği sürede, faaliyetlerin aksamaması ve sürdürülebilir olmasına geçiş sürecinde ciddi sıkıntı yaşadılar. Çünkü yapılan çalışmalar çevrimiçi ortama istenen sürede taşınamadı. Bu durum işlerin aksaması, verilen eğitimin verimsizliği gibi sonuçları meydana getirdi. Bu dönemin en büyük deneyimi teknolojiyi kullananın daha hızlı adapte olmasıyla farkını göstermiştir. Dijitalleşme süreci hepimize tehlike kadar şans getiren büyük bir devrimdir. Bu nedenle, bu dönüşümde her bir yönün zorlukları ve sonuçları hakkında konuşmak önemlidir.

Dijitalleşme ile ilgili süreçte, 1990 yılların sonlarına doğru Web1.0 teknolojisi yerini Web 2.0 


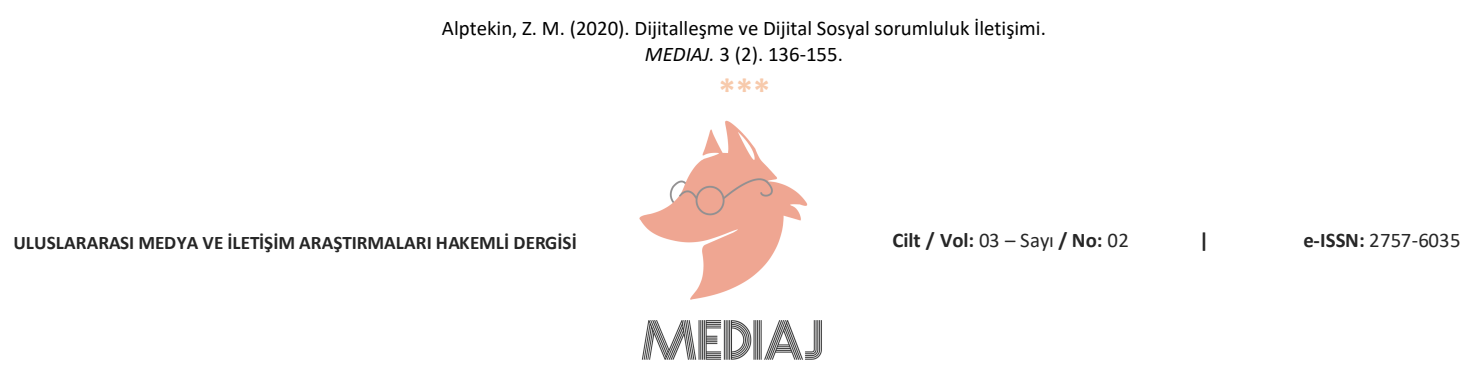

teknolojisine bırakmaya başlamıştır. Web 2.0, Internet teknolojisindeki gelişmeler, arama motorları ve web teknolojisi kullanıcı odaklı içeriklerin üretilmesi konusunda imkân oluşmuştur. Bunun yanı sıra internet ve Web 2,0 teknolojisi bilgi paylaşımını ve haber alma hızını da artırmıştır. Sosyal ağlar, bloglar, mikrobloglar, içerik paylaşım siteleri, podcast, wikiler, sosyal medya siteleri gibi dijital iletişim araçlarının yanında online topluluklar ile iletişim, arama motoru optimizasyonu, online haber bültenleri, online kriz yönetimi ve online kurumsal itibar yönetimi gibi yeni halkla ilişkiler araçlarının ve tekniklerinin, kurumların tüm paydaş grupları ile kurmuş olduğu iletişimi nasıl şekillendirdiği görülmüştür (Koçyiğit,2018, s.11). Web 2.0 döneminde, şirketler sosyal ağ sitelerinin gücünü anlayarak halkın ilgisini çekmek için kendi kurumsal sosyal sorumluluk iletişimlerini bu platformun birer parçası haline getirmektedir. Kurumsal sosyal sorumluluk iletişimine ilişkin bir trend olarak kurumlar Web sitelerine sosyal sorumluluk faaliyetlerine ilişkin bir sayfa açarak, bu projeyle ilgili olan ve takip edenlere yönelik bilgi paylaşımı yapmakta, paydaşlarıyla etkileşimli iletişime geçmekte, geri bildirim almakta, ürünler ve gönüllü işgücü gibi konularda fikir değişimi yapmakta ve tüm bu bilgilerden kaynak oluşturmak gibi konularda paylaşımlar oluşturabilmektedir (Abitbol ve Lee, 2017, s.796).

Aslında dijitalleşme kavramı yeni ve teknoloji odaklı bir yaşam oluşturma kapsamıdır. Eskiden bir araştırma yapmak istediğimizde sadece erişebildiğimiz kitaplardan faydalanılıyordu. Dijitalleşme ile bilgi ve kaynağa kolayca ulaşım sağlanabilmektedir. Bununla birlikte, tüm verilerin ve çıktıların yorumlanabilir ve paylaşılabilir olması da dijitalleşmenin sağladığı avantajlar arasındadır. Dijital dönüşüm, dijital teknoloji ile ilgili olabilecek tüm fırsatları yakalamak ve fayda edinmek amacıyla, ticari faaliyet ve süreçlerin dönüşümü olarak ifade edilir. Buradaki amaç, verimliliği artırmak, süreçleri daha verimli, hızlı ve etkin hale getirmek, ayrıca riski yönetmektir. Dijital dönüşüm sürecindeki amaçlanan eylem, yapılacak olan işleri sadece dijital bir şekilde yaparak gerçekleştirmektir. (Elektrikinfo, 2019).

Dijital dönüşümün tek seferlik bir çalışma değildir. İlk dijitalleşme dalgası, bugün "olgun" olarak kabul edilen teknolojilerin tanıtılması ve benimsenmesidir. Buna veri işlemeyi otomatikleştirmeyi amaçlayan ve uygulanan yönetim bilgi sistemleri iş performansının, telekomünikasyon teknolojilerinin izlenmesi ve raporlanması, geniş bant (sabit ve mobil) ve sesli telekomünikasyon (sabit ve mobil) gibi örnekler verilebilmektedir. İinci dijitalleşme dalgası, internetin ve buna karşılık gelen platformların (arama motorları, pazar yerleri) yayılması, işletmelerin tüketiciler ve işletmeler arasında ağ kurmasını sağlayan etkenler ve işlevlerdir. Üçüncü dalga sayısallaştırma, büyük teknoloji gibi bir dizi ileri teknolojinin benimsenmesini gerektirir (Katz, 2017, s.8). Dijital dönüşüm, toplumu ekonomiden iş operasyonlarına kadar geniş bir yelpazede çeşitli düzeylerde etkilemektedir. Benzer şekilde dijital dönüşümün yeni iş fırsatları sağladığı, istihdam ve girişimciliği etkilediği kaydedilmektedir. Son olarak dijital dönüşümün, kişilerarası ilişkileri ve davranış üzerinde etkili olduğu da öne sürülmektedir (Katz, 2017, s.9).

Önceleri denenmiş ve güvenilir kaynaklar olarak tanımlanan gazeteler, radyo ve televizyon gibi 


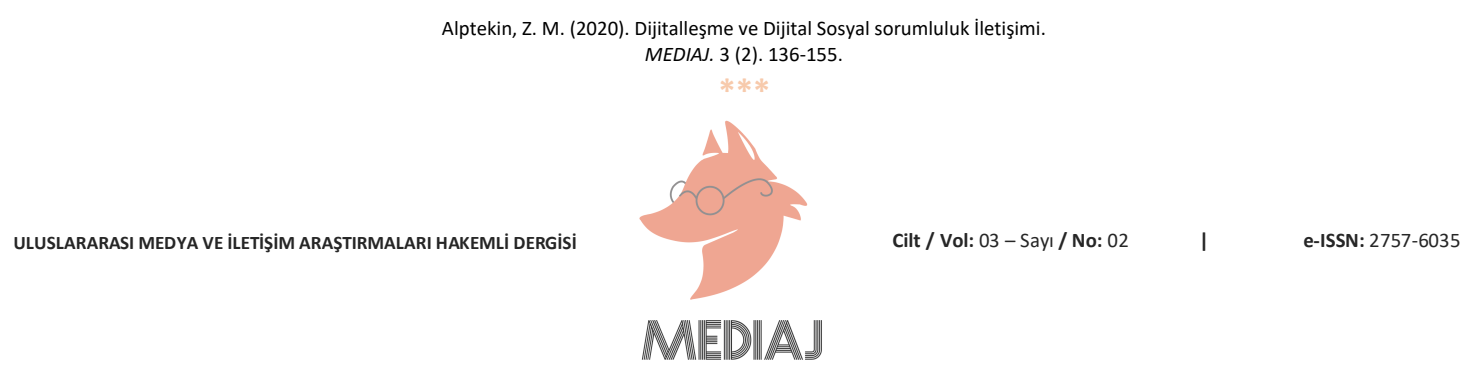

kitle iletişim araçları etkinliği bilinmekte olduğu için şirketler bu kanallar ile iletişim kurmayı tercih etmişlerdir. Mesela bir şirketin tanıtmak istediği bir projesi, duyurmak istediği bir mesajı, markası varsa bir reklam aracılığı yapılmakta olduğu bilinir. Daha sonra, dijital dönüşümün etkisi ile kurumsal iletişim üzerinde kalıcı bir etkisi olan bir değişim başlamıştır. Şirketler iletişim kanallarını kendileri sosyal ağlar sayesinde yayınlamaya başlamış, bu sebeple kitle iletişim araçlarına olan bağımlılıklarından kurtulmuşlardır. Şirketlerin kendi sosyal medya kanalları vardır. Artık bir şirketin kendi podcast kanalına ve sosyal medya kanallarına sahip olması bilinir bir durumdur. "iç̧erik pazarlaması" dönemi nihayetinde gelmiştir. Dijital dönüşüm, iletişim önlemlerini genel olarak daha hızlı ve daha ucuz hale getirmiştir. Büyük ve farklı kitlelere ulaşmak çok daha kolaylaşmıştır. Gündemde olmak için şirketlerin tartışmasız yapması gereken duruma uyum sağlamaktır. Özellikle halkla ilişkiler ile iletişim kanallarının kullanımı için duruma uyum sağlamaktır (Sommer, 2017).

\section{Dijital Çağda Kurumsal Sosyal Sorumluluk: Dijital Sosyal Sorumluluk}

Dünya, özellikle de II. Dünya Savaşı'ndan sonra ortaya çıkan krizden etkilenmiştir. Esas olarak işletmelerin gelirlerini artırmaya odaklandıkları ve ortalama vatandaşların zor yaşam koşullarını değiştirmek için hiçbir şey yapmadıkları bilinmektedir. Küresel ölçekte bu konudaki ilk ciddi faaliyetlerin "sürdürülebilir kalkınma" teriminin ortaya çıkmasıyla başladığı ileri sürülmektedir. Bu noktada kaynakların kullanımını, yatıımların yönü, teknolojik gelişmelere olan eğilim ve kurumsal değişimin hem geleceğe hem de mevcut ihtiyaçlara uygun hale getirildiği bir değişim sürecine geçildiği kaydedilmiştir (United Nations General Assembly, 2018). İnternetin gelişmesi ise, dijital çağdaki kuruluşların kurumsal sosyal sorumluluk faaliyetlerini hedef kitlelerine iletmelerini sağlayan önemli bir iletişim aracı haline gelmesine yol açmıştır. Dijital dönüşüm, insanların geleneksel sorunlarını dijital bir platform üzerinde çözmelerine imkân tanımıştır. Kurumsal sosyal sorumluluk ile ilgili çalışmaların 1980'lerden itibaren giderek önem kazandığı belirtilmektedir. Kurumsal sosyal sorumluluk çalışmalarının pazarlama, yönetim, strateji ve iş etiği dâhil olmak üzere birçok disiplinde dikkat çektiği belirtilmiştir. Geleneksel kurumsal sosyal sorumluluk faaliyetlerini dijital yönteme dönüştürmek kaçınılmazdır (Puwirat ve Tripopsakul, 2019). Dijital dönüşüm şu anda Dördüncü Sanayi Devrimi'nin iş yapma şeklini değiştiren en önemli unsurudur. Dijitalleşme diğer yandan, neredeyse sınırsız bir iletişim ve bağlantı olanakları yelpazesi açar, her alanda bilgi paylaşımını geliştirir ve kurumsal verimlilik ve sürdürülebilirliği geliştirir. Ayrıca, dijital dönüşümün kendisi çözüm gerektiren yeni sosyal ve çevresel sorunları gündeme getirir. Bunlar veri koruma konularını ve yapay zekânın kullanımını içeren konuları içerir (Eisfeller,2020).

Dijital dönüşümün halkla ilişkiler uygulamalarından biri olan sosyal sorumluluk çalışmalarındaki etkisini gösteren kavramlardan biri dijital sosyal sorumluluktur. Dijital sosyal sorumluluk, kurumun bireysel ve toplumsal düzeydeki etik düşüncelerini birleştirerek, giderek dijitalleşen işgücü yapısında sosyal sorumluluk düşüncesine yön vermesi açısından değerlidir. Dijital sosyal 


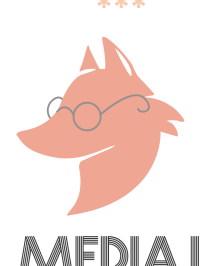

sorumluluk, teknolojik değişimin hem ütopik hem de distopik gelecekleri doğurabileceğinin bilinciyle, bireysel ve toplumsal düzeyde etik kaygıların bir birleşimidir (Joynson,2018). "2017 Küresel Dijital İnfüzyon" araştırmasında Christopher Joynson, tüm şirketler tarafından temel ilkelerinden biri olarak dikkate alınması gereken dijital sosyal sorumluluk faktörlerini değerlendirmelerini önermektedir. Şirketler dijital sorumlulukla, sürdürülebilir otomasyon, dijital erişilebilirlik, yapay zekâ gibi dijitalleşmenin oluşturduğu rahatlıktan faydalanabilir (Joynson, 2018).

Dijitalleşmenin bir ütopyadan distopyaya dönüşmesini önlemek amacıyla, dijital dönüşüm için etik bir pusula gerekir. Artan sayıda şirket bu intiyacı ve kendi dijital sorumluluklarını tanımaktadır. Tanıtımı, kendilerini gönüllü olarak dijital sosyal sorumluluğa adayarak ve dijitalleşmeyle oluşacak sorunlarla başa çıkmak için etik kurallar belirleyerek gösterilmektedir. Dijital sosyal sorumluğa katılımları, şirketlerin dijital ve diğer sektörlerde güven kazanmalarına yol açabilir. Dijital sosyal sorumluluk yasal gerekliliklerin ötesinde, dijital dünyayı etik ilkelere dayanarak şekillendirir. Örneğin, şirketler veri kullanımında açıkça tanımlanmış limitler belirleme ve müşterilere veri toplama kapsamı ve amacı hakkında kapsamlı ve şeffaf bilgiler sunmayı taahhüt edebilirler (Eissfeller,2020).

Dijital dönüşüm ile kullanılan kurumsal sosyal sorumluluk, modern dünyada küresel rekabetçiliğin ve değişikliklerin en önemli faktörlerinden biridir. Bu değişikliklerin sadece ekonomik değil, sosyal sonuçları da Avrupa Komisyonu projelerine ya da Davos'taki dünya ekonomik forumu himayesinde uygulanan programlara konu olmaktadır (Toffler,1980). Yeni ekonominin temeli olan bilgi, dijital dönüşüm sayesinde içerikle doludur ve yeni kavramlar oluşmasına sebep olmuştur: Akıllı cihazlar ve giyilebilir cihazlar, büyük veri, mobilite, bilgi işlem bulutu, sosyal platformlar, bio ve nano-teknolojiler, nesnelerin interneti, yenilenebilir enerji veya hisse ekonomisi örneklerini verebiliriz.

Internet, dijital çağdaki kuruluşlar için bir kurumsal sosyal sorumluluk iletişimi aracı haline gelmiştir. Dijital dönüşüm, insanların geleneksel sorunlarını modern ve dijital bir şekilde çözmelerini sağlamaktadır. Bu nedenle, sadece dijital araçlara dayalı bir dizi etkinlik değildir. Dijital dönüşüm kültürel bir değişikliktir (Orbik,2016, s.93). "Digital social responsibility: search for a sound, responsible in information society" isimli konferansta değerlendirildiği üzere, dijital sosyal sorumluluğun, dijital teknolojinin her bireyin saygınlığının, öz saygısının ve kapasitesinin artırılacağı bir şekilde kullanılması gerekmektedir. Bu araçları kullanımlarında, toplumun üyeleri tüketici değil, bir topluluğun katılımcılarıdır. İnternet şirketlerinin ve yönetenlerin yol gösterici felsefesi, sömürüden ve bağımlılıkların oluşmasından kaçınmak, şeffaflığın rolünü güçlendirmek ve insanların esasen kendi geleceklerini şekillendirmelerine izin vermek olmalıdır (Hyde, 2008).

Bir şirketin seçtiği kurumsal sosyal sorumluluk faaliyetinin marka değerleriyle uyumlu olması önemlidir. Şirket, neden belirli bir nedeni destekleme niyetinde olduğunu sormalıdır. Örneğin, 


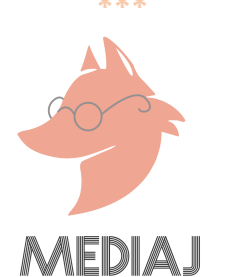

petrol şirketleri kurumsal sosyal sorumluluk programlarının bir parçası olarak genellikle alternatif enerjilerle ilgili araştırmaları desteklemeyi seçerken, büyük perakendeciler giysi işçilerinin güvenliğini savunan kurumlarını desteklemeye çalışacaklar. Hayırseverlik ve dijital teknoloji artık özünde birbirine bağlıdır. Küçük yardım hareketleri, sosyal sorumluluk faaliyetleri dijital ağlar sayesinde çoğu zaman büyük bir ivme kazanabilir. ̈̈lkemizde sosyal sorumlulukla ilgili en başarılı örneklerden bir tanesi gıdaya saygı felsefesi ile gıda israfına karşı sürdürülen ve tamamen dijital platformlarda yer alan Grundig şirketinin üstlendiği "Ruhun Doysun” projesidir. İlgili projenin web sayfasındaki açıklamaya göre, insanların yüzde 94'ü sürdürülebilir hayatı, gıda israfını önemsemektedir ancak ne yapacağını bilmemekte, ya da tek başına bir fayda sağlayamayacağına inanmaktadır. Çalışma bir farkındalık hareketi olarak tamamıyla sosyal ağlar kullanılarak takipçiler ile iletişime geçilmiştir. Instagram, youtube yoğun biçimde kullanılmıştır. Bunun yanı sıra televizyon programı da yapılmıştır (Grundig, 2017).

Dijital bir yaklaşımla, kurumsal sosyal sorumluluk projelerini uyumlaştırmak her zamankinden daha kolay olmuştur. Çevrimiçi tüm eylemler, saha çalışma fırsatları ve genel hayırseverlik faaliyetleri tek bir yerde saklanabilir. Başka bir avantaj, her şeyin önceden inşa edilmiş programların olmasıdır. Dijital uygulamaların gelişi, sivil toplum örgütleri için fırsatlar anlamına da gelir. Yeni ve önemli ölçüde ücretsiz iletişim yolları onlara daha fazla görünürlük sağlar. Internet sayesinde dünyanın her yerinden insanlar en küçük organizasyonları bile tanıyabilirler ve takip edebilirler (Epareborda,2018).

Dijital sosyal sorumluluk dört kategoriden oluşmaktadır. Bu kategorilerin her biri, rekabetçi farklılaşma yaratmak için önemli fırsatlar oluşturan bileşenler içerir.

Bu kategorileri, sosyal kurumsal, ekonomik kurumsal, teknolojik kurumsal ve çevresel kurumsal dijital sosyal sorumluluk olarak tanımlayabiliriz. Tüm bu öğeler kurumsal sosyal sorumluluğun dijital yönlerini ele alır. Sosyal kurumsal dijital sorumluluk, bir kuruluşun insanlarla ve toplumla ilişkisini içerir. Müşterilerin, çalışanların ve diğer paydaşların veri gizliliğinin korunmasına ilişkin konular bu alana dahildir. Aynı zamanda dijital yatırımı olan kurumlar, şirketler, hatta toplumlar arasında sosyal sınıflar ve nesiller olarak aralarında giderek artan bir uçurumun tespit edilmesi gibi, dijital çeşitlilik ve kapsayıcılığın yönlerini de içerir. Ekonomik kurumsal dijital sorumluluk, dijital teknolojilerin ekonomik etkilerinin takip edildiği ve incelendiği yöntemlerle ilgilidir. Örneğin, şirketlerin organizasyon yapılarında yer alan departmanlar ve bu görev sahibi olan kişilerin rol tanımları, dijitalleşmenin getirdiği olanaklarla daha az maliyet, daha fazla verim nasıl elde edilir çalışmaları ve uygulamalarından bahsedebiliriz. Teknolojik kurumsal dijital sorumluluk, teknolojilerin sosyal sorumluluk kapsamında yaratılmasıyla bağlantılıdır. Örneğin, yanlış yapay zekâ algoritmaları, haksız veya ayrımcı uygulamalara yol açabilir. İnsanların gerçekçi bir şekilde söylemedikleri veya yapmadıkları şeyleri yaptıkları gibi gösterilen sahte videolar gibi diğer teknolojilerin de toplum üzerinde zararlı etkileri olabilmektedir. Çevresel kurumsal dijital sorumluluk, teknolojik aletlerin geri dönüşüm fırsatları veya eski bilgisayar ekipmanının atılması 


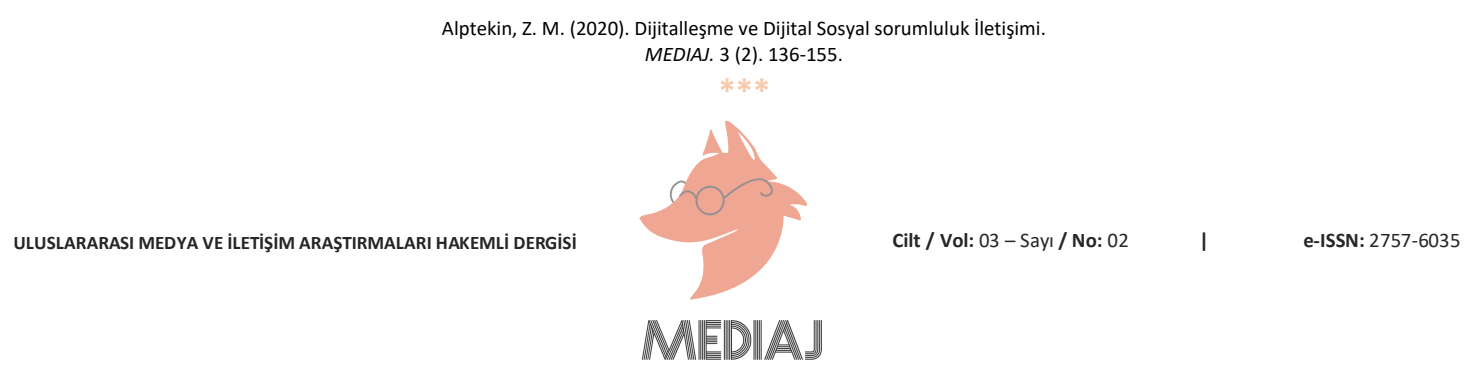

yerine parçaların değerlendirilmesi gibi konular dahil olmak üzere dijital teknolojiler ve fiziksel çevre arasındaki bağlantıyla ilgilidir (Wade, 2020). Organizasyon süreçlerinde uygulamada bu unsurlar mevcut olmasına karşılık, nadiren bir arada dikkate alındığı ve koordine edildiği görülmektedir.

\section{İşletmelerin Kurumsal Sosyal Sorumluluk Çalışmalarının İletişiminde Sosyal Medya}

\section{Kullanımı}

Sosyal medya, medya ve iletişim alanında önemli bir oyuncu haline gelmiştir. 2020 yılında "We are social ve hootsuite" ile birlikte yayımladığı "2020 Dünya İnternet Kullanımı ve Sosyal Medya İstatistikleri" raporuyla dünyadaki İnternet, sosyal medya ve mobil kullanım istatistiklerini değerlendirilmiştir. Rapordan alınan bilgiye göre;

Internet, sosyal medya ve mobil kullanıcı istatistiklerine baktığımızda 4.54 milyar internet kullanıcısı, dünya nüfusunun $\% 59$ 'u, 3.80 milyar sosyal medya kullanıcısı, dünya nüfusunun \%49'u, 5.19 milyar mobil kullanıcısı, dünya nüfusunun \%67'sini oluşturmaktadır." En çok kullanılan sosyal medya platformları ile ilgili 2020 yılı araştırmasında, Facebook 2.49 milyar kullanıcı sayısıyla lider olarak karşımıza çıkmaktadır. En çok kullanılan ikinci sosyal medya platformu olan Youtube'u iki milyar kullanıc ve son olarak WhatsApp 1,6 milyar kullanıcı ile takip etmektedir (Bayrak,2020). Bu araştırmadan edindiğimiz bilgiye göre dijital ağların kullanımı viral biçimde toplumumuzda artmakta ve her şeye yön verir bir gücü elinde tutmaktadır.

Ancak, sosyal medya kullanımının gücü bu verilerle ne kadar etkin olduğu ispatlanmış da olsa, stratejik, planlı ve hatta sürdürülebilir iletişim ile ilgili birçok ortamda hala bilinmediği, etkisine inanılmadığı görülmüştür. Örneğin, İngiltere'nin en iyi 100 şirketi hakkında yapılan bir araştırmaya göre Twitter hesabı olan 88 şirket içinden 7 şirketin tweet adı verilen mesajlardan atmadığı, dört şirketin bu yıl hiç tweet mesaj atmamakla birlikte sadece bir kez Twitter'da aktif paylaşımda bulunduğu ve 61 şirketin kendilerine ait sosyal medya hesapları olmadığı bilgisi alınmıştır (Benvie, 2013, s.4). Tüketiciler ve kurumsal kullanııılar arasında, ayrıca farklı endüstri sektörlerindeki kurumsal kullanıcılar arasındaki bu tutarsızlık, teknoloji ile olan ilişkileri ve ne kadar önem verdikleri hakkında birçok soru getirmektedir. Bunun başlıca nedenleri dijital stratejinin olmaması, sosyal medya kanallarını yönetmek ve izlemek için kaynak eksikliği ve sosyal medya kanallarının etkin kullanımına yönelik yasal ve düzenleyici konularla ilgili bilgi eksikliğidir (Mack, 2013, s.2).

Kurumsal sosyal sorumluluk iletişiminde nesiller ve onların dijital iletişim araçlarını kullanımı konusunun da önemli bir yer teşkil ettiği söylenebilir. Buna göre öncelikle dijital yerli kavramını tanımlamak yerinde olacaktır. Günümüzde nesiller arası bakış açısının ve tercihlerin nasıl değiştiği deneyimlenmektedir. Y ve Z nesilleri dijital yerliler olarak bilinen bir çağdadır (Prenksy, 2001, s.1). Bu demektir ki, zaten teknoloji ile çok yakın olan bu nesil temsilcilerine kurumsal sosyal sorumluluk ile ilgili iletişiminde sosyal medyanın kullanımı çok alışagelmiş olduğundan, 


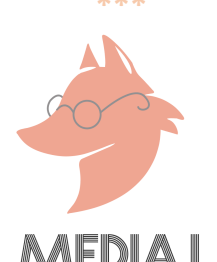

iletişim kanalı olarak sadece sosyal ağları dikkate alacaklardır. Teknolojinin kurumsal sosyal sorumluluk uygulamasında getirdiği ilk değişiklik, şirketin dünyayla iletişim kurma ihtiyacıdır. ikinci değişiklik, kurumsal sosyal sorumluluğun, kişilerle iletişim kurma yolu olmasıdır. Teknolojik gelişmeler nedeniyle insanların gerçekte ne istediğini bilmek daha kolay olmuştur. Üçüncü değişiklik, kendi başına kurumsal sosyal sorumluluğun gerçekleştirilme şeklidir. Artık günümüzde bu nesillere hitap eden çalışmalarla üniversitelerde araştırma merkezleri oluşturulmuştur. Dijital yerliler, yeni nesil temsilcileri olarak, kurumsal sosyal sorumluluğu teknolojiyle geliştirmekte ve başarılı sonuçlar elde etmektedir (Gayatri,2019, s.1).

Başlangıçta, bir şirketin kurumsal sosyal sorumluluk ile ilgili yaptıklarına yönelik iletişimi için şirket web sitesinde sürdürülebilirlik raporunda yer vermesini yeterli olarak gördükleri anlaşılmıştır. Ancak daha yakın zamanlarda şirketler mesajlarını iletmek için sosyal medya kullanıp, böylece kurumsal sosyal sorumluluk çıktılarıyla tüketicilere ulaşmaktadır. Şirketler için sosyal medya, belirli grupları hedeflemek için etkili bir platformdur. Yani kurumsal sosyal sorumluluk bilgilerinin artık önceki yıllara göre daha etkili bir şekilde yönlendirilebileceği anlamına gelmektedir (Bolat, 2016, s.2). Yapılan araştırmaya göre, Fortune 500 şirketleri içinde yer alıp sosyal sorumluluk sahibi kuruluşların Twitter hesaplarından, yapılan iletişimin görünür olma olasııı̆ının daha yüksek olduğu ve sonuçlar sebebi ile şirketlerin sosyal ağlara yatırımlarının arttığı tespit edilmiştir (Lee vd., 2013). Markalar kurumsal sosyal sorumluluk için (Web siteleri, sosyal raporlar, ödüller ve etkinlikler, ilgili pazarlamaya neden olan tüm etkenler) iletişim kurmak amacıyla çok çeşitli kanallar kullanır. Bu alandaki çalışmalar çok önemlidir, çünkü sosyal raporlar ve web siteleri, geleneksel yöntemlerin aksine kurumsal sosyal sorumluluk reklamlarındaki son zamanlardaki artışı açıklayacak olan doğrudan reklamdan daha az etkili olan daha yumuşak tanıtım teknikleri olarak kabul edilmektedir (Motwani, 2012, s.41). Yapılan araştırmalar, tüketicilerin, kurumsal sosyal sorumluluk faaliyetlerinde aktif ve bilinir olan bir markaya karşı ilgilerinin daha çok olma, daha çok çıkan haberlere dikkat etme ya da marka ürünlerini tercih etme olasılıklarının daha yüksek olduğunu bulmuştur (Sen ve vd., 2007, s. 224). Kurumsal sosyal sorumluluk konusunda sosyal medyanın kullanımıyla farklı tutumları olan tüketiciler üzerinde daha önce yapılmış çalışmalar test edilmiştir. Katılımcıların \%45'i satın alma kararlarının bir parçası olarak kurumsal sosyal sorumluluk faaliyetlerine çok dikkat etmediklerini, \%36'sının etik dışı duyumlar aldıkları bir şirketten satın alırken kendilerini suçlu hissetmediklerini belirterek, sonuç olarak tüketicilerin diğer satın alma kriterleri gibi konularda aldıkları mesajı, mesela ürün fiyatlandırması, daha önemli olarak değerlendirdiğini göstermektedir (Bolat,2016, s.2). Kurumsal sosyal sorumluluk projelerinde sosyal medyanın hangi kanalı kullanılırsa iletişimin daha etkin, hızlı ve ses getirici olduğu takip edilmelidir. Her geçen gün yapılan yeni raporlamalar ile sosyal medyanın bir şirket, bir proje veya etkinlik üzerindeki farklı ölçümleri sayesinde daha ileri, kaliteli ve deneyime dayalı verilerin değerlendirmesi ihtiyaç bazında doğru kullanıımalıdır.

Dijital iletişim, daha geniş kitlelere ulaşma potansiyeli olduğundan hızla büyüyen bir dalga etkisi yaratabilir. Bu nedenle, çok sayıda paydaşın beklentilerini karşılamada bir denge kurmak ve 


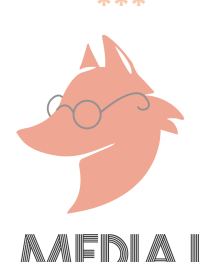

insanlarla iş birliğine dayalı çalışma ilişkilerine girmek şirketlerin yararınadır. Paydaşlarla süregelen iletişim, bir şirketin itibarı, marka imajı, müşteri sadakati ve yatırımcı güveni için somut faydalara dönüşebilir (Deephouse, 2000). Şirketler kurumsal sosyal sorumluluk raporlarını tüm takipçilere tüm yalınlığı ile sunmalıdırlar. Bu bildirimleri yaparken medya iş birliğini kullanırlar. Medya iş birliği yapmak çoğu zaman zor olmakla birlikte, şirketler televizyonda veya basında yayın kapsamı gibi bağımsız, nesnel kaynaklardan olumlu medya kapsamı elde etmek için çok çaba göstermelidir. Kurumsal haberler, iş etiği dikkate alınarak, uzmanlık alanlarında itibar edilen yayınlar tarafından rapor edilirse veya bir işletme "Fortune" dergisi gibi bağımsız kuruluşlar tarafından iyi bir kurumsal sosyal sorumluluk derecesi alırsa, şirketin itibarını büyük ölçüde artıracaktır (Colleoni, 2013, s. 228). Ama artık bu tür raporlarını kendi web sayfalarında ve diğer kurumsal sosyal medya sayfalarında yayınlayabilir ve değerlendirmeleri kendileri alabilirler.

Sosyal medya yoluyla iletişim, geleneksel medyaya göre dinamiktir. Bloglar, elektronik forumlar, sosyal ağlar gibi sosyal yazılımların küresel yayılımı şirketlerin umutları ve tüketici gruplarını çekmesini kolaylaştırmıştır. Sosyal medya, iletişim süreçlerini hızlandırmak ve kuruluşlar ile çeşitli izleyiciler arasında doğrudan etkileşimi, diyaloğu ve katılımı arttırmak için teknolojik potansiyele sahiptir. Bu tür etkileşimli iletişim "viral” olarak adlandırılır, çünkü fikirler ve görüşler ağ aracılı̆ııla salgın hastalıklar gibi yayılır. Bu kanallar son derece güvenilir kaynaklar olarak algılanmaktadır (Hansen vd., 2011, s.34). Çevrimiçi iletişim, daha geniş kitlelere ulaşma potansiyeli bulunduğundan büyüyen bir etki yaratır. Sosyal medya kurumlar ve çevreleri arasındaki iletişim dinamiklerini değiştirmiştir. Bu çevrimiçi ağlar, trend olan konuları da işaret edebildikleri için etkili izleme araçlarıdır.

Dijital medya iş dünyası iletişimcilerinin ve pazarlamacılarının kendilerini en son sürdürülebilirlik konularında güncel tutmasına yardımcı olabilir. Kurumsal sosyal sorumluluk etkileyicileri, belirli konularda veya uzmanlıkta kolayca tanımlanabilir. Örneğin, işletmeler ve müşteriler, paylaşılabilir içeriklerinin görünürlüğünü artırmak için hashtag (\#) kullanmayı öğrendiler. En popüler hashtag örneklerinden bazıları şunları içerir: \#CSR, \#StrategicCSR, \#sustainability, \#susty, \#CSRTalk, \# Davos2016. Hashtag'ler hayır kurumları, çevreci toplum kuruluşları hakkında farkındalık yaratmak için kullanılabilir (Ayeh ve Law 2013, s. 132).

Sosyal medya kanalları olan Facebook, Twitter ve Linkedın yaygınlığı, sosyal ağları dünyadaki birçok kişi ve işletme için tanıdık kanallar haline getirmiştir. Bu ağlar markalar, şirketler ve aktivistler için çok popüler iletişim noktaları haline gelmiştir. Özellikle Twitter, milyonlarca kişi tarafından mesaj yayınlamak ve bilgisayarlarda ve cep telefonlarında konuşmalarda yabancılarla etkileşim kurmak için kullanılan en popüler araçlardan biri haline gelmiştir. Linkedın, özellikle kişisel markalaşma için bir başka etkili araçtır. Şirketler Linkedın'deki favori gruplarını oluşturmak veya katılmak için kullanabilir. Bu girişimleri teşvik ettikleri ve sürdürülebilirlik fikirlerini paylaştıkları için kurumsal sosyal sorumluluk iletişimi amacıyla da kullanılabilirler. Buna ek olarak, Pinterest ve Instagram, kullanıcılarının ağlarıyla görüntü, fikir paylaşmalarını sağlar. Bu 


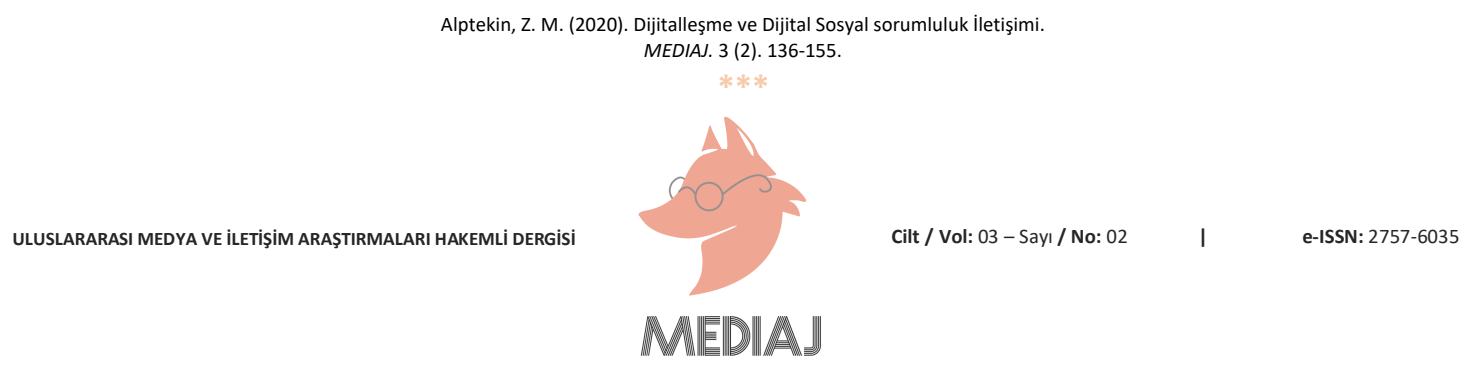

sosyal medya sürdürülebilirlik gündemi bağlamında da alakalı olabilir. İşletmeler görsel ve grafiksel içerik yoluyla kurumsal sosyal sorumluluk iletişimini paydaşlara gösterebilirler (Schultz vd., 2011, s. 20).

\section{Kurumsal Sosyal Sorumluluk, Sosyal Medya İletişim ve Paydaş Teorisi}

Kurumsal sosyal sorumluluk, şirketlerin ekonomik, sosyal ve çevresel etkilerini nasıl yönettikleri, farklı paydaşlar ve toplum grupları ile ilişkileri ve müzakereleri üzerine odaklanmaktadır (Ihlen vd., 2011). Edward Freeman, "Paydaş teorisi" ile dikkatleri paydaşlara kaydırarak sosyal sorumluluğun gelişimine katkıda bulunmuştur (Edward, 1984). Paydaşlar, Edward Freeman tarafından "bir kuruluşun amacının gerçekleştirilmesinden etkilenebilecek herhangi bir grup veya birey olarak" tanımlanmıştır.

Mette Morsing ve Majken Schultz tarafından geliştirilen kurumsal sosyal sorumluluk iletişim modeli (Morsing ve Schults, 2006) amacı, şirketin paydaşlarına bilgi sunduğu tek yönlü bir iletişim kanalı oluşturmaktır. İkinci olarak model ile ilgili bir adım daha ileri gidilir ve çevreden gelen görüşlerin ve dikkate alındığı, ancak her zaman şirketi ekonomik fayda veya kar arayışındaki olası değişikliklere uyarlamak amacıyla iki yönlü bir kanal açılır. Üçüncü olarak ise model, bazı karşııklı yararlara yol açan eylemleri gerçekleştirebilmek için paydaşlarla diyaloğun teşvik edildiği gerçek bir iki yönlü iletişim kanalının oluşturulmasıdır.

İki yönlü iletişimde yeni perspektifler açan bir araç hiç kuşkusuz ki internettir. Birbirine bağlı ağların bu küresel sistemi, günlük ve sosyal yaşamın herhangi bir alanında genel olarak ilişkileri, iletişimi, tüketimi ve katılımı anlama şeklimizde devrim yaratmıştır (Viñarás, Cabezuelo ve Seijas, 2014). Şirketler ister kamu ister özel olsun, web sitelerini müşterilerine, tüketicilerine veya diğer paydaşlarına yaklaşmak için bir pencere olarak kullanmaya başlamıştır. En güçlü iletişim aracı olan internet, kurumsal sosyal sorumluluk iletişimi için yeni bir yol sunar (Capriotti ve Moreno, 2007). Internet üzerinden tek yönlü kurumsal sosyal sorumluluk iletişimi üzerine yapılan ampirik çalışmalar esas olarak kurumsal web sitelerinin analizine odaklanmıştır.

Tüm çevrimiçi sosyal ağların kurumsal sosyal sorumluluk etkinliği için bir araç olarak tam potansiyeli ile kullanılmamaktadır (Capriotti, 2011; Castelló vd., 2013; Kemna, 2013). Şirketler tarafından sosyal medya etkileşimine olan bu ilgi eksikliği, kurumsal sosyal sorumluluk, Twitter ağındaki en önemli 30 kurumsal hesaptan 41.864 Twitter mesajını analiz eden (Etter, 2013) tarafından doğrulanmıştır. Bu çalışmanın sonuçları, şirketlerin çevrimiçi sosyal ağlarda kurumsal sosyal sorumluluk sorunları hakkında paydaşlarıyla aktif olarak iki yönlü iletişim kurmadıklarını göstermiştir.

Çevrimiçi sosyal ağların şirketlere ne ölçüde dahil edildiğini araştırmak amacıyla 2014 yılında piyasa değeri açısından en önemli 20 İspanyol şirketinden oluşan bir örneklem üzerinde bir analiz yapılmıştır. Şirketlerin sayısı ve örnekleme birimi, bu 20 şirketin çevrimiçi sosyal ağ profilleri Facebook ve Twitter'da yayınladıkları mesajlardır. Bu şirketler grubu, IBEX 35 olarak bilinen 


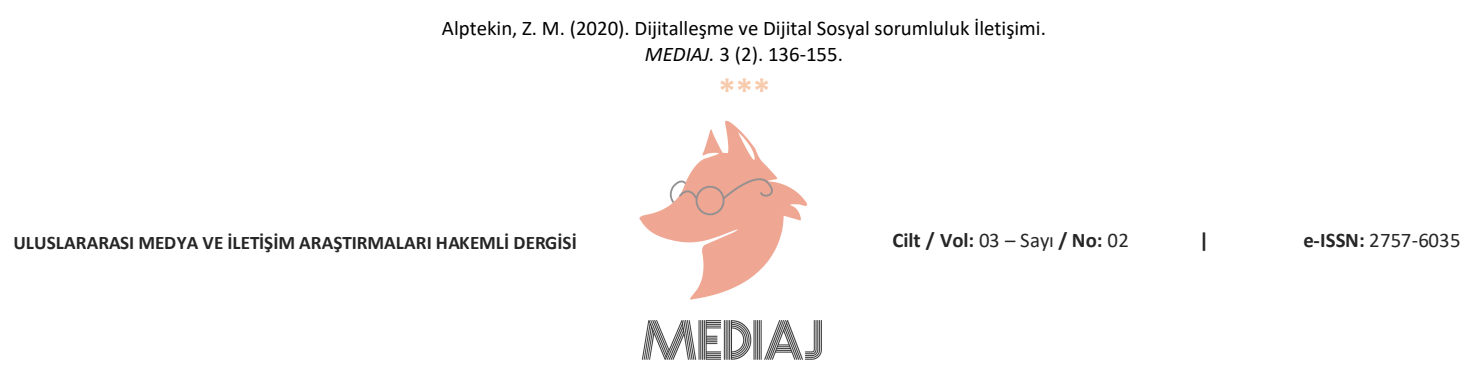

şirkete aittir. Bu şirketler örgütleri yönlendirdiği için seçilmiştir. Yaptıkları, diğer İspanyol ve uluslararası şirketler için bir referanstır. Bu büyük İspanyol şirketleri, ana uluslararası kurumsal sosyal sorumluluk derecelendirmelerinde en üst sıralarda yer almaktadır ve ispanya, bu derecelendirmelerin en üstünde en çok uluslararası şirkete sahip Avrupa ülkesidir. Bunun nedeni Avrupa ve İspanyol yasalarının yanı sıra paydaşların baskısıdır (Olcese, 2013).

Kullanılan metodoloji, IBEX 35 şirketlerinin çevrimiçi sosyal ağ profillerinde yayınladıkları mesajlar için kapsamlı bir arama gerçekleştirmektir. Böylece elde edilen veriler daha sonra değerlendirilebilir durumdadır. Son üç yılda IBEX 35 şirketleri, çevrimiçi sosyal ağlardaki varlıklarını önemli ölçüde artırmıştır. Bir yandan, Twitter'da profili olan şirketlerin yüzdesi 2010'da \%51,4'ten 2013'te \%71,4'e yükselmiştir (Estudio de Comunicación, 2013). Öte yandan Facebook'ta, yüzde 2010 'da \%25, 7 idi ve 2013'te \%57,1'e çıkmıştır. Sosyal ağlara olan bu artan katılım, bu şirketlerin son yıllarda nasıl geliştiğine dair daha derin bir bilgiye sahip olmayı daha önemli hale getirilmiştir. Kurumsal sosyal sorumluluk yönetimi ve iletişimi söz konusudur. Sadece basit bir iletişim aracı olarak değil, aynı zamanda sosyal ağların kullanıcılarıyla diyalog ve etkileşime izin veren bir araç olarak gelişimlerini belirlemek de çok önemli hale gelmiştir.

Araştırma için veri toplama için zaman aralığı 2011-2013 yılları olarak belirlenmiştir. Bu üç yıllık dönem boyunca sosyal ağlarda mesajların sayısı, manuel olarak kodlanmaları çok yükselmiştir. Bu sorunu çözmek için, tek tip örneklemi sağlamakta sadece kasım ayını analiz etmek karar verilmiştir. Bu ön koşullar oluşturulduktan sonra, şirketlerce öngörülen zaman aralığında hem facebook hem de twitter'da yayınlanan her türlü mesaj (gönderi ve tweet) toplandı ve analiz edilmiştir. Daha sonra mesajlar, şirketin kurumsal sosyal sorumluluk ile bağlantılı olup olmadı̆̆ına göre sınıflandırılmıştır. Bunu yapmak için, bir mesajın içeriği "Global Reporting Initiative" tarafından oluşturulan kurumsal sosyal sorumluluk kategorilerinden en az biriyle ilgiliyse, bir mesajın bir kurumsal sosyal sorumluluk mesajı olarak kabul edildiği içeriğin değerlendirilmesinden oluşan bir kriter kullanılmıştır (Gómez, 2012). Son olarak ve çalışmanın temel amaçlarından biri olarak, şirketin kullanıcılarıyla olan etkileşimi (tek yönlü ve iki yönlü iletişim), onlarla kurduğu diyaloğa dayalı olarak incelenmiştir.

416'sı Facebook'tan ve 5,106'sı Twitter'dan olmak üzere toplam 5.522 mesaj toplanılmıştır. Tüm mesajlar Kasım 2011, 2012 ve 2013 aylarında yayınlanmıştır. Bu mesajlar analiz edilerek şirketin kurumsal sosyal sorumluluk ile ilgili olanlar seçilmiştir.

Sonuç olarak IBEX 35 şirketlerinin yıllar içinde sosyal ağlardaki varlıklarını kademeli olarak artırdığı görülmektedir. Facebook'ta toplam mesaj sayısı altı kat, Twitter'da üç kat artmıştır. Kurumsal sosyal sorumluluk ile ilgili görevlerin sayısı da önemli ölçüde artmıştır. Bu kaynak, her sosyal ağdaki toplam mesaj yayınlamasına göre kurumsal sosyal sorumluluk ile ilgili gönderilerin yüzdesini analiz edilmesine olanak tanır. IBEX 35 şirketleri, kurumsal sosyal sorumluluk hakkında bilgi sunmak için Facebook'u daha fazla kullanmaktadır. 2011'de kurumsal sosyal sorumluluk ile ilgili gönderilerin \%12,5'inden 2013'te \%26,6'ya yükselmiştir. Facebook'u farklı konularda 


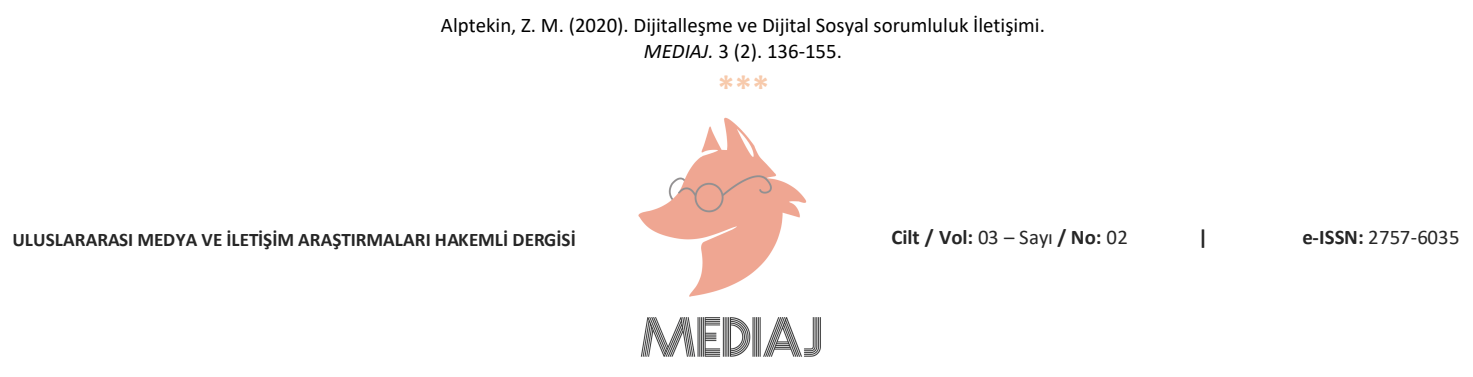

iletişim kurmak için daha ilgi çekici olarak görülmektedir. Tweet sayısının 2010 yılında \%16 olduğu ölçülmüştür (Cortado ve Chalmeta, 2016, s. 7). Elde edilen veriler, Twitter'da kurumsal sosyal sorumluluk ile ilgili çok sayıda mesajın yayınlandığını, ancak kullanıcılardan çok az, hatta neredeyse hiç yanıt almadıkları gösterilmiştir. Facebook'ta yayınlanan mesajlar kullanıcılardan daha fazla ilgi görmekte ve kurumsal sosyal sorumluluk ile ilgili gönderi sayısı Twitter'dan daha az olsa da bu sosyal ağın özellikleri sebebi ile takipçilerle daha fazla etkileşimde olduğunu ispatlamıştır. Facebook'ta, şirket ile kullanıcıların yanıtları arasındaki etkileşimde 2012'ye göre hafif bir artış vardır. Bu, iki yönlü iletişimin yüzde olarak önemli ölçüde düştüğü Twitter'da bilgisiyle çelişmektedir.

Yapılan araştırmanın sonuçlarında tek yönlü ve iki yönlü iletişim arasında var olan önemli farklılıkları göstermektedir. Araştırma sonucunda değerlendirildiği üzere, IBEX 35 şirketleri, sosyal ağları kurumsal sosyal sorumluluk iletişimi için giderek daha sık kullanmaktadır. Ancak esas yaptıkları takipçileri ile bağlantı kurma ve etkileşimde bulunma konusunda olabilen tüm fırsatlardan yararlanmadan, sadece haberleri yaymak için kullanmaktadır. Bu bilgiye paralel, bunu yapmaya çalışan şirketler, kullanıcılarla etkin iletişime girme konusunda çok istekli olmadıkları bilgisi elde edilmiştir. Çıkarılabilecek ana sonuç, IBEX 35 kuruluşlarının çevrimiçi sosyal ağları yalnızca başka bir iletişim kanalı olarak kullandığı ve paydaşların ilgi ve beklentilerini bulmak için geri bildirim kullanılmadığı değerlendirmesidir (Cortado ve Chalmeta,2016, s. 9).

Bu çalışmadan elde edilen sonuçlar, IBEX 35 şirketleri tarafından son yıllarda sosyal ağlarda yayınlanan sürdürülebilirlik ve kurumsal sosyal sorumluluk ile ilgili bilgi miktarında açık bir ilerleme olduğunu göstermektedir. Çevrimiçi sosyal ağları yalnızca bir pazarlama ve reklam kanalı olarak kullanan bu 20 şirketten bazıları varken, diğerlerinin hem Twitter'da hem de Facebook'ta profilleri var olduğu, ancak neredeyse hiç kullanmadıkları tespit edilmiştir (Cortado ve Chalmeta, 2016, s.13). Bu bilgiyle anlıyoruz ki şirketler ne kadar güçlü ve toplumsal konulara duyarlı da olsa, halen çevrimiçi ağların gücünden faydalanma konusunda değerlendirme aşamasında olan şirketler varlığını sürdürmektedir.

Dolayısıyla dünyada dijital iletişim teknolojileri alanında hızlı bir gelişme yaşanmasına rağmen; bu yeni dünyada kurumsal sosyal sorumluluk uygulamasında etkin iletişim sağlanması hala eksik olan bir konu olarak değerlendirilmektedir. Geleneksel medya tek yönlü iletişim süreçleri tarafından yönetilir, farklı paydaş gruplarıyla açık ve etkileşim, tek yönlü iletişimle yeterli olamamıştır. Konu ile ilgili yapıımış araştırmalarda da görüldüğü üzere kurumsal web sitelerinin kurumsal sosyal sorumluluk için stratejik iletişim kaynağı olarak yetersiz kullanıldığını göstermiştir. Bununla birlikte, dijital medya insanların birbirleriyle etkileşim ve iş birliği yapmasına imkân vermişken halen tek yönlü bir iletişim kanalı kullanılması etkin değildir. Örneğin, insanlar, toplumu ve çevreyi etkileyebilecek kurumsal operasyonlar hakkında daha fazla şeffaflık talep etmek için sosyal medyada seslerini daha güçlü duyurabilir, mesaj yazabilir, görüşlerini sosyal medya kanalları aracılığı ile iletebilir (Gomez,2018, s.197). Sosyal medya 


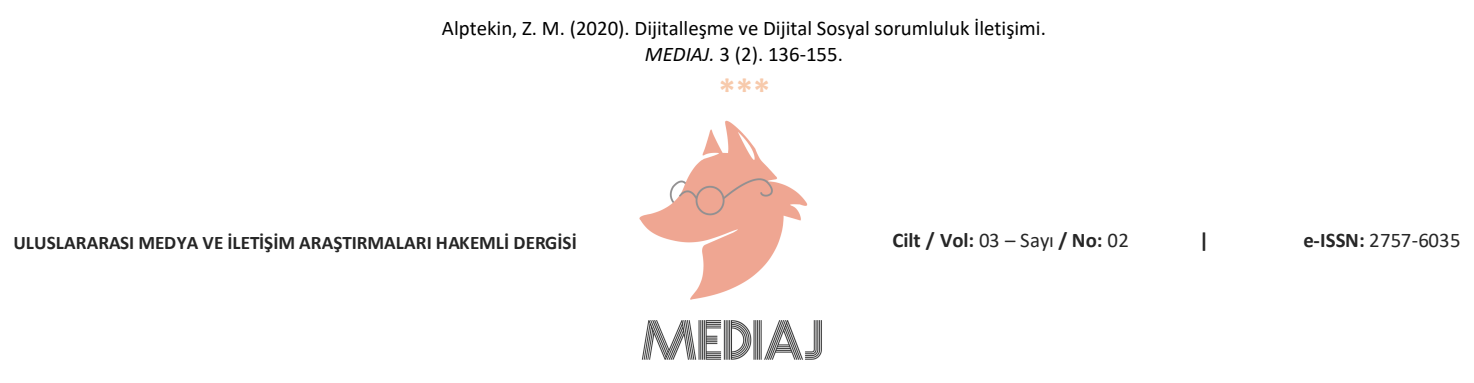

kamuoyuna, kurumla ve yapmış oldukları sosyal sorumluluk faaliyetlerine ilişkin fikirlerini ve beklentilerini beyan etme fırsatı vermekteyken, aynı şekilde kurumlara da kamuoyuna kendilerini ve yapmış oldukları faaliyetleri tanıtma fırsatını sağlamaktadır (Cho vd., 2017, s.53).

\section{SONUÇ}

Günümüzde sosyal sorumluluk ülkelerin, iş dünyasının ve akademinin öncelikli konularından biridir. Kurumsal sosyal sorumluluk ekonomik boyutun ötesine geçen ve şirketlerin rutin iş uygulamaları sırasında dikkate almaları gereken sosyal yükümlülüklerin türü ve kapsamını ifade etmektedir (Tomaselli ve Melia, 2014, s. 324).

Yeni çağın teknolojik gelişmelerin her alanda yarattığı etki, kurumsal sosyal sorumluluk amaçı projelerin dijital platformlara taşınmasına fırsat yaratmıştır. Sosyal ağların kullanıcı sayısının giderek artması şirketlerin iletmek istedikleri her türlü bilgi, çalışma ve sosyal sorumluluk faaliyetlerinin düşünülenden daha hızlı ve etkili bilinmesini sağlamaktadır. Bu gelişmeler ışığında işletmeler, tüketicilerine daha yakın olmak ve internetteki görünürlüğünü artırmak için sosyal medyayı iletişim stratejilerine dahil etmeye başlamışlardır. Şirketler, dijital sosyal sorumluluk iletişimi için, bu alanda yaptığı faaliyetleri, hazırladıkları raporları tüm dijital platformları kullanarak sunmaktadır. İşletmeler sürdürülebilir iletişimi sağlamak ve takipçilerin bu kurumsal sosyal sorumlulukla olan ilgilerini devam ettirmek amacıyla Twitter, Facebook, Instagram gibi sosyal medya ağlarını aktif şekilde kullanmayı göz ardı etmemektedirler.

Burada dikkat çeken nokta, günümüzde dijital iletişim araçlarının kullanımı ve kurumsal sosyal sorumluluk kavramı hakkındaki bilgi, ilgi ve benimsenme derecesi artmasına rağmen, işletmelerin kurumsal sosyal sorumluluk çalışmalarının iletişiminde kullanıcıyı içeriğe dahil edecek, katacak ve onlarla etkileşim kuracak şekilde bu mecraları stratejik kullanamamalarıdır. Dijital iletişim araçları kurumsal sosyal sorumluluk çalışmalarının dijital platformlara aktarılmasını sağlayarak hem işletmelere dijitalleşme, ileri teknolojiye öncü olma gibi fırsatlar sunmakta; hem de toplumdaki bireylerin geleneksel iletişim platformlarında hiç olmadığı kadar çok bu projeleri benimsemesini, bağış yapmasını, kurumsal sosyal sorumluluk projesinin farkındalığını artırmasını ve kurumsal sosyal sorumluluk projelerinin çok daha geniş bir alana duyurulmasında onları iletişimin merkezine yerleştirmektedir. Şirketler çevrimiçi sosyal ağların pazarlama ve iletişim aracı olarak faydalarını bilmekteler. Buna rağmen, bir araç olarak sosyal ağların kurumsal sosyal sorumluluk konularında etkileşimi için potansiyeli hala tam olarak kullanılmamaktadır. Çevrimiçi sosyal ağlar, şirketlerin sosyal sorumluluk iletişiminde etkili bir çözümdür. Karşııklı fayda kapsamında eylemleri gerçekleştirebilmek için paydaşlarla diyaloğun teşvik edildiği iki yönlü iletişim kanalının oluşturulmasında İnternet iletişimde yeni bakış açısı yaratmaktadır.

İki yönlü sosyal sorumluluk iletişimini çevrimiçi sosyal ağlar üzerinden ele alınıp değerlendirilmesi, etkileşimli bir yaklaşım kullanarak etkileri konusunda analiz edilmesi, birçok 
şirket için çevrimiçi kullanımdan ne oranda fayda gördüğünü gösterecektir. Dijital sosyal sorumluluk kavramı dikkate alındığında çevrimiçi sosyal ağlar, şirketlere kurumsal sosyal sorumluluk iletişimine iyi bir çözüm sunar. Paydaşlarla kurumsal sosyal sorumluluk konularında iki yönlü bir iletişim yaklaşımıyla etkileşim kurmaya izin verirler. Geçmişte şirketler, kurumsal sosyal sorumluluk konularında paydaşlarla etkileşimde çok az ilgi gördüğü bilinmekte, günümüzde şirketlerin kurumsal sosyal sorumluluk iletişimini çevrimiçi sosyal ağlar üzerinden ele alıp almadığını ve eğer öyleyse, etkileşimli bir yaklaşım kullanarak doğru şekilde yapıp yapmadıklarını analiz etmek, değişen ve gelişen toplumda bir ihtiyaç haline gelmektedir.

\section{KAYNAKÇA}

Abitbol, A. \& Lee, S.Y. (2017). Messages on CSR-Dedicated Facebook Pages: What Works and What Doesn't, Public Relation Review.

Ayeh, J.K., Norman, A. \& Law, R. (2013). "Predicting the Intention to Use ConsumerGenerated Media for Travel Planning." Tourism Management.

Bayrak, S. (2001). Iş Ahlakı ve Kurumsal Sosyal Sorumluluk (1. Basım). İstanbul: Beta Basım Yayım.

Bayrak, H. (2020). 2020 Dünya internet, Sosyal Medya ve Mobil Kullanım Istatistikleri. Erişim: 12.11.2020, https://dijilopedi.com/2020-dunya-internet-sosyal-medya-ve-mobilkullanim-istatistikleri.

Bolat, E., Osborne, N. \& Memery, J. (2016). Meaningful CSR Communication Via Digital Media- Competitive Paper.

BWA Digital, (2020). Dijital Dönüşümün Iş̧letmelere Faydaları Nelerdir. Erişim: 12.11.2020, https://www.bwa.com.tr/dijital-donusumun-isletmelere-faydalari-nelerdir.

Capriotti, P. \& Moreno, A. (2007). Corporate Citizenship and Public Relations: The Importance and Interactivity of Social Responsibility Issues on Corporate Websites. Public Relations Review, 33, 84-91. doi:10.1016/j. pubrev.2006.11.012

Capriotti, P. (2011). Communicating Corporate Social Responsibility Through The Internet And Social Media. In $\varnothing$. Ihlen, J. Bartlett \& S. May (Eds.). The Handbook of Communication and Corporate Social Responsibility (pp. 358-378). Chichester: Wiley. http://dx.doi.org/10.1002/9781118083246

Castelló, A. \& Ros, V. (2012). CRS Communication Through Online Social Media. Revista Latina De Comunicaciòn Social.

Cortado, F. J. \& Chalmeta, R. (2016). Use of Social Networks as A CSR Communication Tool. Cogent Business \& Management. 
Cho, M., Furey, L.D. \& Mohr, T. (2017). Communicating Corporate Social Responsibility on Social Media: Strategies, Stakeholders, and Public Engagement on Corporate Facebook, Business and Professional Communication Quarterly, Vol.80 (1).

Colleoni, E. (2013). CSR Communication Strategies for Organizational Legitimacy in Social Media. Corporate Communications: An International Journal, 18, no. 2.

Cortado, F.J. \& Chalmeta, R. (2016). Use of Social Networks as a CSR Communication Tool, Cogent Business \& Management. Erişim: 12.11.2020, https://doi.org/10.1080/23311975.2016.1187783

Culnan, M. J., McHugh, M. J. \& Zubillaga, J. I. (2010). How Large U.S. Companies Can Use Twitter and Other Social Media to Gain Business Value. MIS Quarterly Executive, 9, 243-259.

Du, S., Bhattacharya, C. B. \& Sen, S. (2010). Maximizing Business Returns to Corporate Social Responsibility (CSR): The Role of CSR Communication. International Journal of Management Reviews, 12 (1).

Dutot, V., Lacalle Galvez, E., \& Versailles, D. W. (2016). CSR Communications Strategies Through Social Media and Influence on E-Reputation: An Exploratory Study. Management Decision.

Edward, F. R. (1984). Strategic Management: A Stakeholder Approach. Boston, MA: Pitman.

Esrock, S.L. ve Leichty, G.B. (1998). Social Responsibility and Corporate Web Pages: SelfPresentation or Agenda- Setting, Public Relations Review.

Epareborda, V. (2018). Five Benefits of Digitalizing Your CSR Program. Erişim: 16.06.2020, https://alayagood.com/blog/5-benefits-of-digitalising-your-csr-program/

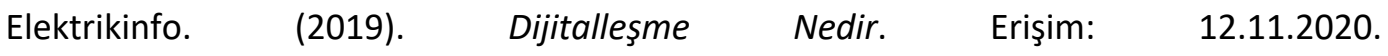
https://elektrikinfo.com/dijitallesme-nedir/.

Eissfeller, C. (2020). Corporate Digital Responsibility. Erişim: 16.10.2020, https://dmexco.com/de/stories/corporate-digital-responsibility-deshalb-ist-eine-digitale-ethikunerlaesslich/.

Etter, M. (2013). Reasons for Low Levels of Interactivity. Public Relations Review, 39, 606608. Erişim: 16.10.2020, http://dx.doi.org/10.1016/j.pubrev.2013.06.003

Fieseler, C., Matthes, F., \& Meckel, M. (2010). Corporate Social Responsibility in the Blogosphere. Journal of Business Ethics. 91, no. 4.

G.C. Kane, D. Palmer, A.N. Philips, D. Kiron \& N. Buckley (2017). Achieving Digital Maturity. Adapting Your Company to a Changing World. Erişim: 18.11.2020, https://sloanreview.mit.edu/projects/achieving-digital-maturity 
Gayatri, J. (2019). CSR in the Digital ERA - Access on the CSR Communication of Companies and Identification of Services for CSR, International Journal of Innovative Technology and Exploring Engineering (IJITEE) ISSN: 2278-3075, Volume-8, Issue-11S.

Glynn, M. \& Faulds, D. J. (2009). Social Media: The New Hybrid Element of the Promotion Mix. Business Horizons, 52, 357-365.

Gomez, L. M. (2018). CSR Communication Through the Lens of New Media. In Sustainability and Social Responsibility of Accountability Reporting Systems (pp. 197-217). Springer, Singapore.

Gómez, L., Chalmeta, R. \& Sosa-Valera, J. C. (2012). Usage and Importance of Social Media for Corporate Communication and Stakeholder Engagement. In V. L. Crittenden, J. Hair \& N. Terblanche (Eds.), Thriving in a New World Economy. World Marketing Congress-Cultural Perspectives in Marketing (pp. 56-59). Atlanta: Academy of Marketing Science.

Grundig, (2017). Ruhun Doysun Yolculuğu. Erişim: 12.11.2020, https://www.ruhundoysun.com/yazilar/ruhun-doysun-yolculugu.

Hyde, K. (2008). Digital Social Responsibility: Search for A Sound, Responsible Information Society. Erişim:

12.11.2020, https://www.japansociety.org/digital_social_responsibility_search_for_a_sound_responsible_i nformation_society, japansociety.org.

Icsb.org (2018). Digital Social Responsibility: The Role of Information Technologies and CIO In. Erişim: 12.11.2020, https://icsb.org/wp-content/uploads/2018/11/Digital-SocialResponsibility_the-role-of-Information-Technologies-and-CIO-in-Corporate-SocialResponsibility1.pdf

İhlen, O., Bartlett, J. L. \& May, S. (2011). Corporate Social Responsibility and Communication. Erişim: 13.11.2020. http:// dx.doi.org/10.1002/9781118083246.

Iillia, L., Romenti, S., Rodriquez-Canovas, B., Murtarelli, G. \& Carroll, C. E. (2015). Exploring Corporations Dialogue About CSR in the Digital Era. Journal of Business Ethics, 1-20.

Joynson, C. (2018). Corporate Digital Responsibility: Principles To Guide Progress. Erişim: 15.05.2020, https://atos.net/en/blog/corporate-digital-responsibility-principles-guideprogress.

J., Schulz, D., Fischer, D., Hetze, K., Laws, N., Lüdecke, G. \& Rieckmann, M. (2013). Communication Regarding Sustainability: Conceptual Perspectives and Exploration of Societal Subsystems. Sustainability, 5, 2976-2990. Erişim: 16.10.2020, http://dx.doi.org/10.3390/su5072976

Kane. G.C., Palmer. D, Philips, A.N., Kiron, D \& Buckley; N. (2018). Achieving Digital Maturity. Adapting Your Company to A Changing World. Erişim: 12.11.2020, https://sloanreview.mit.edu/projects/achieving-digital-maturity. 
Kane, G. (2018). Digital Maturity, Not Digital Transformation. Erişim: 12.11.2020, https://sloanreview.mit.edu/article/digital-ma- turity-not-digital-transformation.

Mack, J. (2013). Pharma's Digital Media Adoption Curve. Pharma Marketing News, 12(6), 2-6. Erişim: 12.11.2020, http://www.pharma-mkting.com/news/pmnews1206-article01.pdf.

Moxley, A. (2014). Corporate Social Responsibility Corporate Digital Age. Erişim: 16.06.2020, https://www.huffingtonpost.co.uk/adrian-moxley/corporate-social-responsibility

Morsing, M. \& Schultz, M. (2006). Corporate Social Responsibility Communication: Stakeholder Information, Response and Involvement Strategies. Business Ethics: A European Review 15, no. 4.

Murhphy, C. (2019). Investopedia. Why Social Responsibility Is Important. Erişim: 12.11.2020, https://www.investopedia.com/ask/answers/041015/why-social-responsibilityimportant-business.asp.

Morsing, M. \& Schultz, M. (2006) Corporate Social Responsibility Communication: Stakeholder Information, Response and involvement strategies. Business Ethics: A European Review, 15, 323-338.

Motwani, S. (2012). Communicating CSR Is More Challenging Than Paying CSR. International Journal of Research and Development, 1.

Olcese, A. (2013). Report About the Corporate Social Responsibility in Spain. Report for the European Commission, Spain. Erişim: 18.10.2020, http://ec.europa.eu/ spain/pdf/informeresponsabilidad-social.pdf.

Orbik, Z. (2016). Humanistic Dimension of Business Ethics. Business Ethics and Sustainable Development. Interdisciplinary Theoretical and Empirical Studies, no. 2.

Puwirat, W. \& Tripopsakul, S. (2019). The Impact of DSR On Customer Trust Brand Equity: An Evidence from Social Commerce in Thailand. European Research Studies, Journal Volume XXII, issue 2. Erişim:

Katz, R. (2017). Social and Economic Impact of Digital Transformation on the Economy. https://www.itu.int/en/ITUD/Conferences/GSR/Documents/GSR2017/Soc_Eco_impact_Digital _transformation_finalGSR.pdf.

Orbik, Z. \& Zozulaková, V. (2019). Corporate Social and Digital Responsibility. Erişim: 12.11.2020.https://content.sciendo.com/configurable/contentpage/journals $\$ 002 \mathrm{fmspe} \$ 002 \mathrm{f2}$ $7 \$ 002 f 2 \$ 002$ farticle-p79.xml, Silesian University of Technology, 2 Constantine the Philosopher University in Nitra, Published.

Ros-Diego, V. J. \& Castelló-Martínez, A. (2012). CSR Communication Through Online Social Media. Revista Latina de Comunicación Social. 
Sen, S, Bhattacharya, C. A. \& Du, S. (2007). Reaping Relational Rewards from Corporate Social Responsibility: The Role of Competitive Positioning. International Journal of Research in Marketing, 24 (3).

Schultz, F., Sonja, U. \& Göritz, A. (2011). Is the Medium the Message? Perceptions of and Reactions to Crisis Communication via Twitter, Blogs and Traditional Media. Public Relations Review 37, no. 1.

Sommer, M. (2017). How Digitalization Affects Public Relations? Erişim: 12.11.2020, http://contenttales.com/how-digitalization-affects-public-relations/.

Toffler, A. (1980). The Third Wave. New York: William Morrow and Co.

Tomaselli, G. \& Melia, M. (2014). The Role of Interactive Technologies for CSR Communication. Journal of International Scientific Publications: Economy \& Business.

United Nations General Assembly (2017). Report of the World Commission on Environment and Development. Erişim: 12.11.2020, http://www.un-documents.net /ourcommon-future.pdf.

Vernuccio, M. (2014). Communicating Corporate Brands Through Social Media: An Exploratory Study. International Journal of Business Communication.

Viñarás, M., Cabezuelo, F. \& Seijas, L. (2014). El futuro de la RSE en España: Análisis del Borrador "Estrategia Española de RSE" Desde la Comunicación Corporativa y las Relaciones Públicas [The future of CSR in Spain: analysis of the draft "Spanish CSR strategy" from the corporate communications and public relations view]. Erişim: 16.10.2020, retrieved from http://www.foro2014.com/

Waters, R. \& Williams, J. (2011). Squawking, Tweeting, Cooing, and Hooting: Analyzing the Communication Patterns of Government Agencies on Twitter. Journal of Public Affairs, 11, 353363. Erişim: 14.11.2020, http://dx.doi.org/10.1002/pa.385

Wade, M. (2020). Digital Resilience: Corporate Responsibility in the Digital Era. Erişim: 12.11.2020. https://sloanreview.mit.edu/article/corporate-responsibility-in-the-digital-era, MIT Sloan Management Review.

Whelan, G., Moon, J. \& Grant, B. (2013). Corporations and Citizenship Arenas in the Age of Social Media. Journal of Business Ethics, 118, 777-790. Erişim: 16.11.2020, http://dx.doi.org/10.1007/s10551-013-1960-3.

Zozulak, J. (2018). Interaction of Philosophy and Natural Sciences in Byzantine Empire. Scientific Letters of The University of Zilina, vol. 20, no. 1A, pp. 8-15. 